\title{
Complementary alternative medicinal systems: An overview
}

\author{
S. Patil Minal, B. Patil Shailesh, P. Chittam Kailaspati, P. Joshi Umesh \\ Department of Pharmacognosy, DCS's A.R.A. College of Pharmacy, Nagaon, Dhule, Maharashtra, India
}

\begin{abstract}
Traditional systems of medicines are playing an important role in providing health care to a large section of population, especially in the developing countries. Indian systems of medicine are among the well-known global traditional systems of medicine. In this review, an attempt has been made to provide general information pertaining to different aspects of these systems. The aspects covered include information about historical background, conceptual basis; different disciplines studied in the systems, research and development aspects. Unani System of medicine is based on established knowledge and practices relating to the promotion of positive health and prevention of diseases. Homeopathy is a system of medicine, which believes in a specialized method of treatment of curing diseases by administration of potency drugs, which have been experimentally proved to possess the power of producing similar artificial systems on human beings.
\end{abstract}

Correspondence:

S. Patil Minal,

DCS's A.R.A. College of Pharmacy,

Nagaon, Dhule, Maharashtra, India.

E-mail: minalpatilpharma@gmail.com

Keywords: Indian system of medicine, Unani, homeopathy system

\section{Introduction}

It is a well-known fact that traditional systems of medicines always played an important role in meeting the global health-care needs. They are continuing to do so at present and shall play a major role in future also. The system of medicines which are considered to be Indian in origin or the systems of medicine, which have come to India from outside and got assimilated into Indian culture are known as Indian Systems of Medicine. India has the unique distinction of having six recognized systems of medicine in this category. They are- Ayurveda, Siddha, Unani and Yoga, naturopathy and homeopathy. Although homeopathy came to India in the $18^{\text {th }}$ Century, it completely assimilated into the Indian culture and got enriched like any other traditional system; hence, it is considered as part of Indian Systems of Medicine. Apart from these systems, there are large numbers of healers in the folklore stream who have not been organized under any category. In the present review, the attempt would be made to provide a brief profile of three systems to familiarize the readers about them so as to facilitate the acquisition of further information. ${ }^{[1-16]}$

\section{Access this article online}

Website: http://www.jpbs-online.com

E-ISSN: 2321-0125

DOI: $10.31555 / j p b s / 2018 / 6 / 2 / 13-17$

How to cite this article: Minal PS, Shailesh BP, Kailaspati PC, Umesh PJ. Complementary alternative medicinal systems: An overview. J Pharm BioSci 2018;6(2):13-17.

Source of Support: Nil, Conflict of Interest: None declared.

\section{Unani System of Medicine}

The Unani system of medicine originated in Greece. Hippocrates is known as the father of this system of medicine. The theoretical framework of Unani medicine is based on his teachings. There were other Greek scholars who followed in his footsteps to enrich this system considerably. In the $9^{\text {th }}$ Century, the Arabic and Persian physicians imbibed Unani system of medicine. In India, the Arabs introduced the Unani system of medicine, and soon it caught the attention of the masses. The Delhi Sultans, the Khiljis, the Tughlaqs and the Mughal emperors provided state patronage to the scholars. This was a golden period of the Unani medicine as it virtually spread all over the country finding immediate favor with the people at large.

The Unani system suffered a temporary setback during the colonial rule but was revived soon after independence, with the government recognizing it as one of the Indian systems of medicine and taking steps to develop and propagate it. According to the principles of Unani medicine, disease is a natural process, its symptoms are the reactions of the body to the disease, and the primary function of the Unani physician is to aid the natural forces of the body. Unani medicine is based on the "Humoral Theory," which presupposes the presence of four humors - Dam (blood), Balghum (phlegm), Safra (yellow bile), and Sauda (black bile) - in the body. The temperaments (mizaj) of people are expressed by the words sanguine, phlegmatic, choleric, and melancholic, according to the amount of each of these four humors prevalent in the human body respectively. ${ }^{[8,9]}$

The humors themselves are assigned temperaments-blood is hot and moist, phlegm is cold and moist, yellow bile hot and dry, and 
black bile cold and dry. There is a unique humoral constitution in every person representing his state of health. To maintain a healthy balance, there is a power of self-preservation or adjustment called Quwwat-e-Mudabbira (medicatrix naturae). A weakening of this power causes an imbalance in the humoral composition and causes disease. What the Unani physician actually tries to do is to prescribe medicine, which helps the body to regain this power and thereby restoring the humoral balance. Correct diet and digestion is integral to this system.

The Unani system of medicine emphasizes on diagnosing a disease through Nabz (pulse), Baul (wine), Baraz (stool), etc. Besides, it gives due importance to the surroundings and the ecological conditions on the state of health of humans. The six essential prerequisites (called Asbab-e-Sitta Zarooriya) for the prevention of diseases in the Unani system are air, food, and drinks, bodily movement and response, psychic movement and response, sleep, and wakefulness, and excretion and retention.

Various types of treatment are employed in the Unani system. These include regimental therapy (Ilaj-bit-Tadbeer), dietotherapy (Ilaj-bitghiza), pharmacotherapy (Ilaj-bit-Dawa), and surgery (Jarahat). The regimental therapy comprises venesection, cupping, diaphoresis, diuresis, Turkish bath, massage, cauterization, purging, emesis, exercise, and leeching.

Dietotherapy tries to treat certain ailments by administration of specific diets or by regulating the quantity and quality of food. Pharmacotherapy deals with the use of naturally occurring drugs, mostly herbal, though drugs of animal and mineral origin are also used. In Unani medicine, single drugs or their combinations in raw forms are preferred over compound formulations. The naturally occurring drugs used in this system are usually free from any side effects while drugs that are toxic in crude form are first processed and purified in many ways before use so as to make them free of any kind of side effects.

\section{Hakims}

These are people, who have gained professional knowledge either institutionally, or otherwise, and impart treatment based on Unani therapy. The practitioners of Unani Medicine are scattered all across the country forming an integral part of the national health-care delivery system. As on January 1999, the estimated number of registered Unani practitioners in India was approximately 40748 (source: Indian system of medicine and Homeopathy in India, 1998). Out of these, more than half (i.e., 21205) are non-institutionally qualified. The number of Unani practitioners, on an average, increased by $1.7 \%$ annually between 1990 and 1998. The majority of this increase was due to an increase in the institutionally qualified practitioners.

All the drugs used in compound formulations are safe and non-toxic. These drugs are prepared according to the specific process and methods. Before preparation of Unani drugs toxicity of drugs are kept in mind, and so the toxic ingredient is purified and detoxified. Due to this process, the toxicity is reduced to nil and the efficacy remains. Hence, the Unani drugs are absolutely safe.

In the basic principles and concepts, the human body is considered to be made up of the following components.

- $\quad$ Arkan (Elements), Mizaj (Temperament), Akhlat (Humours), Aza (Organs), Arwah (Spirit), Quwa (Powers), Afa'l (Function).

\section{Elements (Arkan)}

These are four, i.e., air, water, earth, and fire. In general, these four elements represent several other elements found in the modern science. There are four states denoting the temperaments of these four elements.

Air: Hot and moist,

Fire: Hot and dry,

Earth: Cold and dry,

Water: Cold and moist.

\section{Temperaments (Mizaj)}

The interaction between the chemical combinations of four elements produces various states which determine the temperament of an individual human being, plants, and minerals. Temperament (Mizaj) is simply defined as having the following states and their combinations:

- Hot single - Compound hot and dry

- Dry - Hot and moist

- Cold - Cold and dry

- Moist - Cold and moist.

\section{Humours (Akhlat)}

The humors are actually the body fluids which are classified broadly in four. The fluid of the body contains various hormones, enzymes, and humors. They are responsible for nutrition to the whole of the body. These fluids are (a) primary, (b) secondary.

- Primary fluids are four humors, i.e., blood, phlegm, yellow bile, and black bile.

- Secondary fluids are hormones, enzymes, and plasma, etc.

\section{Organs (Aaza)}

Organs are composed of cell, tissues, nerves, and blood vessels. Various organs of the body and health in disease condition of each individual affect the state of health.

\section{Pneuma-gaseous material (Arwah)}

The pneuma is a life force which carries of different powers, without which human body is dead. This is a source of life and vitality.

Modes of treatment are four:

- Regimental therapy dietotherapy

- Pharmacotherapy surgery.

Regimens are five as under:

- Exercise, massage, hammam, douches, regimen of geriatrics. 
Hammam and massage therapy are available in Govt. Nizamia General Hospital (Unani) Hyderabad, Andhra Pradesh. Cupping therapy as another specialty treatment of Unani is available in Central Research Institute., (CCRUM) Hyderabad, Andhra Pradesh.

\section{Faculties (Qawa)}

Faculties/powers are of three kinds.

- Natural powers

- Psychic powers

- Vital powers

\section{Functions (Afaal)}

This includes movements of various organs. It is necessary to ensure that various organs should be in proper shape and condition to perform proper functions.

\section{Uses}

In the following acute conditions Unani drugs take immediate action.

- Indigestion, acidity, flatulence, diarrhea, dysentery, bronchitis, coryza and Cattarrh., abdominal pain, Urticaria, and other ailments.

The misconception that the Unani drugs act only in chronic diseases is absolutely incorrect. The arthritis, bronchial asthma, sinusitis, hepatitis, etc. becomes chronic due to repeated administration of allopathic drugs. These can be cured in acute condition by Unani drugs. As almost all the Unani drugs are used orally or locally, and injectables are not used in the system, therefore they act like the allopathic drugs through the same route.

\section{Homeopathic System of Medicines}

Homeopathy was founded 200 years ago by Dr. Samuel Hahnemann who gave direction to this branch of medicine with his famous concept "similia similibus curentur" ('let like cure likes'). Homeopathy is made up of two Greek words, "Homeo" meaning similar and 'Pathos' meaning suffering. Therefore, it simply treats with remedies in minute doses, which produce symptoms similar to the disease, when taken by healthy people. Moreover, it is based on the natural law of healing- "Similia Similibus Curantur," which means "likes cure likes." The method was given a scientific thought by Dr. Samuel Hahnemann (1755-1843), in the early $19^{\text {th }}$ century. ${ }^{[10-12]}$

Homeopathy is the one of the most rapidly growing systems of medicine and is practiced all over the world. The gentleness of its cure and the safety of its pills have made the medicine system quite popular. In the Indian context, homeopathy is in use for more than a century and a half. It is well blended with the roots and traditions of the country and is now recognized as one of the national systems of medicine. Due to its mass appeal, it provides health care and solutions to large number of people.

\section{Homeopathic medicine}

Homeopathy is a system of medicine, which are ages old. It is popular in almost all the parts of the world, providing relief to the sick, from their pain and suffering. One of the most significant aspects of homeopathy deals with the treatment of not only the disease but also of the whole person as an individual.

\section{Homeopathy treatment}

Homeopathy involves a careful observation of the patient and the symptoms of the disease exhibited by him. This includes a detailed examination of patient's history including all the aspects of his life such as physical, mental, and emotional. It also includes the various incidents in his life, which might have led to the problem.

Homeopathy is a science of medical treatment with a philosophy of its own, and its therapeutics is based on certain fundamental principles. Like all other systems of medicine, homeopathy is also guided by some elementary guidelines. These principles are the building blocks of this science and guide the homeopaths till date.

Homeopathy is based on three basic principles:

1. The rule of simile

2. Testing of medicament in healthy human being

3. The principle of homeopathic doses.

Hahnemann studied many substances that led him to establish new rules of cure by use of substances which are capable of creating such disturbances in healthy human beings, by use of same substances in micro-quantitative level. The system of homeopathy that he developed is holistic as it considers the entire individual's physical, mental, and emotional symptoms and treats the sum of the symptoms according to the "rule of simile." In 1866 , Samuel Hahnemann founded the homeopathic central pharmacy to manufacture and sell homeopathic medicine. He also created prescribed standards for homeopathic pharmaceuticals production known as "Pharma Copoeia homeopathic Polyglotta" which was later revised and is known as German Homeopathic Pharmacopoeia which serves as an international reference for homeopathic standards today.

In India, the history of homeopathy is linked with the name of Dr. Honiberger, a French man who brought homeopathy to India in 1829. He was invited to treat Maharaja Ranjit Singh of Punjab. He, later on, started practicing in Calcutta. The influx of homeopath and homeopathy was more in Calcutta and later on became the site of the first homeopathy College in India.

The system spread from eastern region to U.P, Delhi, Kerala, and Karnataka. In the second phase of expansion, the spread took place in Northern and Western India. Dr. M.L. Sirkar was first qualified physician in India.

Subsequently, the Government of India (GOI) constituted a Homeopathic Inquiry Committee in 1948, which submitted its 
report in 1949. A few state governments extended recognition by the suitable enactment in fifties, finally leading to GOI recognizing the system in 1960. With this followed the constitution of an advisory committee, Homeopathic Pharmacopoeia Committee and Central Council of Homeopathy. A Homeopathic Pharmacopoeia Laboratory was established in 1975, which formed the nucleus of the establishment of Central Council for Research in Homeopathy.

Today, there are over 1,50,000 institutionally qualified homeopaths and over 2.5 lakhs practitioners under certain legal rights and protection given to them. In addition, there are over ten lakh persons or more patronizing it as self-medicating homeopathy knowing the person.

According to a recent survey conducted by Dabur Research organization, the market size of homeopathic industry in India is estimated to be of Rs. 600 crores which hold 14\% share in total Indian system of medicine and homeopathy.

\section{Homeopaths}

The persons who have the knowledge of homeopathy and who offer treatment to other persons are the practitioners who have gained professional knowledge through some training or the education in this field. Moreover, these are the people, who are responsible for the spread and success of the system.

In the exercise of power conferred by the Homeopathy Central Council Act 1973, the central council has taken expeditious steps toward putting medical education in Homeopathy and practice on a proper footing keeping in view the national requirements.

Legal definition of homeopathic medicines GOI "homeopathic medicines includes any drug which is recorded in homeopathic proving or therapeutic efficacy of which has been established through long clinical experience as recorded in authoritative homeopathic literature of India or abroad and which is prepared according to the technique of homeopathic pharmacy and covers combination of ingredients of such homeopathic medicines which is administered by parental route."

GOI listed 2373 drugs used as homeopathic medicines in 1965, which was subsequently increased to 3000. In this system, the most frequently used drugs are called Polycrest. Moreover, in this context, it should be noted that for homeopathic medicines clinical and biological trial are conducted where they are tested for toxicity on long term, short term, and medium term use. Currently, there are 863 manufacturing units all over India of which 100 can be said to be organized. Out of these, three units are those belonging to foreign companies such as Willmar Schwabe, Sharda Boiron and Bioforce. The companies in organized sector are professionally managed production facilities with modern equipment and technology. The main products that are manufactured by these units are medicines. Other products such as shampoo, pastes, and creams are also manufactured by some of these units. All these things are sold under the prescription of medical practitioners. However, the market for homeopathic products other than drugs is very small in India.

Since homeopathy originated from Germany, the industry is still using 150 raw materials, which are of imported origin like plants not grown in India, and minerals not found in India. In homeopathic industry, the raw material are taken and processed. From them, mother tincture is obtained. This is diluted further in alcohol. It is interesting to note that in homeopathy the raw material requirement is not substantially large because they are used in very small quantities and then it is further diluted. However, the environment required is pollution free, dust free, and bacteria free. Normally, bigger companies undertake extraction, as it involves significant technical know-how. Dilution, however, does not require much complication, though the environment requirements still remain. There is also a prevalent practice of mixing two or more homeopathic medicine and selling it in the brand name. Estimated sale of such branded products constitutes $30 \%$ of total sales.

The technology involved in homeopathy has evolved over time, with scientists and pharmacists working in the industry taking American, German, and French methods of production as their base. The manufacturing base in India is, however, not homogeneous. The production facilities available in the organized manufacturing sector are far more superior to the facilities for smaller units. Larger units maintain a quality control unit and research testing laboratories, which the smaller operations cannot always afford.

\section{References}

1. Government of India, Department of Ayush, Ministry of Health \& Family Welfare. Pharmacopoeial Laboratory for Indian Medicines. Ghaziabad; 1970.

2. Tripathi M, Maheshwari MC, Jain S. Ayurvedic medicine and epilepsy. Neural J Southeast Asia 2000;5:1-4.

3. Mishra K. Caring Ambassadors hepatitis C choices. Ayurvedic Medicine. $4^{\text {th }}$ ed. Clifton Park, NY: Milady/Cengage Learning; 2008. p. 153-65.

4. Ayurveda: The Traditional Health Science of India, A bulletin Published By Maharshi Charak Ayurveda Clinic and Research Center: 1-18.

5. Ayurveda and Siddha by Government of India, Department of AYUSH, Ministry of Health \& Family Welfare. Pharmacopoeial Laboratory for Indian Medicines. Ghaziabad; 2008.

6. Krishnamurthy $\mathrm{KH}$, Chandra G. Siddha system of medicine: A historical appraisal. Indian J Hist Sci 1984;19:43-53.

7. Wilson E, Rajamanikackam GV. Herbs used for Siddha system of medicine. Indian J Tradit Knowl 2007;6:678-86.

8. Unani System of Medicine by Government of India, Department of AYUSH, Ministry of Health \& Family Welfare. Pharmacopoeial Laboratory for Indian Medicines. Ghaziabad; 1978.

9. Jafri MA. Unani System of Medicine and Present Health Delivery System. Bangalore, India: National Institute of Unani Medicine.

10. Master F. Life Style Ailments and Homoeopathy. A Blog. p1-21.

11. Flesner S. Caring Ambassadors Hepatitis C Choices. Homeopathic Medicine. $4^{\text {th }}$ ed. Maryland Heights: C.V. Mosby; 2008. p. 189-96.

12. Homeopathy System of Medicine by Government of India, Department of Ayush, Ministry of Health \& Family Welfare. Pharmacopoeial Laboratory for 
Indian Medicines. Ghaziabad; 2017.

13. Hough H, Dower C. Profile of a Profession: Naturopathic Practice. San Francisco: Center for the Health Professions, University of California; 2001.

14. Steriti R. An Introduction to Naturopathy and Naturopathic Medicine. New York: American Association of Naturopathic Physicians; 2007.
15. IARC. History of use of traditional herbal medicines. Some Traditional Herbal Medicines, IARC Monographs. Vol. 82. Lyon, France: IARC Press; 2002. p. 43-68.

16. Hui KK. Harmonizing Traditional Chinese and Modern Western Medicine: A Perspective, Department of Medicine, UCLA School of Medicine; 1999. 